MARIAN ZALESKO

\title{
INSTYTUCJONALNE PODSTAWY INTEGRACJI POLSKI Z UNIĄ EUROPEJSKA
}

\section{WSTĘP}

Analizy dotyczące integracji gospodarczej zajmują poczesne miejsce w literaturze naukowej, zarówno polskiej, jak i obcojęzycznej. Proces konsolidacji gospodarek, zwłaszcza w Europie w ramach rozbudowy Unii Europejskiej, jest bardzo istotną kwestią badaną przez przedstawicieli różnych nauk społecznych, m.in. ekonomistów, socjologów, politologów, prawników, historyków. Studia dotyczące tematyki integracji często przybierają charakter analiz interdyscyplinarnych.

Niniejsze opracowanie poświęcone zostało problematyce przygotowań Polski do akcesji do Unii Europejskiej. Celem artykułu jest przedstawienie roli wybranych instytucji w kształtowaniu fundamentów integracji naszego kraju ze Wspólnotą Europejską. Droga Polski do struktur unijnych jest ciągle fascynującym polem badawczym.

\section{INTEGRACJA GOSPODARCZA A INSTYTUCJE}

Z punktu widzenia etymologii termin „integracja” wywodzi się z łacińskiego wyrażenia integratio. Oznacza ono tworzenie, zespalanie, scalanie. Integracja polega zatem na łączeniu pewnych części w całość, co może m.in. oznaczać konsolidację organizmów społeczno-gospodarczych, np. państw.

Integracja w Europie ${ }^{1}$, co podkreśla K. Łastawski, opiera się na trwałym dorobku cywilizacyjnym, uformowanym w głównej mierze przez kulturę grecką,

1 J. McCormick daje do zrozumienia, że „Części Europy były jednoczone w różnych epokach w różnych celach - inaczej było w czasach Rzymian, inaczej w czasach Franków, Habsburgów, Napoleona czy Hitlera - jednak podczas gdy wielu marzyło o zjednoczeniu, idea odsunięcia na bok poszczególnych nacjonalizmów w interesie współpracy regionalnej zdobyła poparcie społeczne i po- 
prawo rzymskie i uniwersalistyczne idee chrześcijańskie. Jego zdaniem do czynników sprzyjających rozbudowie i umacnianiu wspólnych instytucji europejskich można zaliczyć: dziedzictwo praw i wolności człowieka, równość i solidarność, rządy prawa, pluralizm światopoglądowy, tolerancję oraz demokratyczne reguły funkcjonowania państw² ${ }^{2}$ B. Balassa wśród celów integracji wymienia między innymi: wzrost efektywności struktur ekonomicznych, stymulowanie wzrostu gospodarczego, eliminację dysproporcji rozwojowych na scalonym obszarze ${ }^{3}$.

Ze studiów literatury wynika, że istnieje wiele definicji integracji. W ujęciu F. Machlupa integracja jest procesem łączenia odrębnych gospodarek w rozleglejsze regiony gospodarcze ${ }^{4}$. W interpretacji Z. J. Kameckiego przez integrację należy rozumieć wytworzenie się, w oparciu o wykształconą jednolitą strukturę ekonomiczną, pewnego tworu gospodarczego obejmującego grupę krajów, która ze względu na wysoki stopień wewnętrznych powiązań gospodarczych i osiągniętą w wyniku tego wewnętrzną spoistość ekonomiczną wyodrębnia się z całokształtu gospodarki światowej ${ }^{5}$ K. Bajan integracją określa proces scalania różnych organizmów gospodarczych i narodowych w jeden organizm skoordynowanych działań, mający wspólne cele o charakterze ekonomicznym, społecznym i politycznym ${ }^{6}$.

Za J. Tinbergenem można wyróżnić integrację negatywną i integrację pozytywną. Integracja negatywna służy znoszeniu przeszkód w przepływie dóbr i czynników produkcji na skonsolidowanym terytorium. Natomiast integracja pozytywna ma na celu ujednolicenie polityki gospodarczej w obrębie zintegrowanego obszaru ${ }^{7}$.

Proces integracji wpisał się w pewnym sensie w kształtowanie tożsamości kontynentu europejskiego. Dziedzictwo Europy tworzone było przez rozwój prądów umysłowych oraz różnych doktryn społeczno-ekonomicznych, które na przestrzeni wieków obejmowały swym zasięgiem cały kontynent bądź jego fragmenty. Również obecnie istotnym zagadnieniem jest współpraca narodów na rzecz ustanowienia wspólnych wartości i zbudowania Europy pokoju i przyjaźni.

lityczne dopiero po II wojnie światowej”; J. McCormick, Zrozumieć Unię Europejskq, Wydawnictwo Naukowe PWN, Warszawa 2010, s. 55.

2 K. Eastawski, Historia integracji europejskiej, Wydawnictwo Adam Marszałek, Torun 2011, s. 11. don 1962.

Szerzej zob. w: B. Balassa, The Theory of Economic Integration, George Allen \& Unwin, Lon-

4 F. Machlup, Integracja gospodarcza - narodziny i rozwój idei, Państwowe Wydawnictwo Naukowe, Warszawa 1986, s. 18.

5 Z.J. Kamecki, Pojęcie i typy integracji gospodarczej. „Ekonomista” 1967, nr 1, s. 93-94.

6 K. Bajan, Polityka gospodarcza i spoteczna. Polska w Unii Europejskiej, Wydawnictwo Naukowe Wyższej Szkoły Kupieckiej, Łódź 2005, s. 89.

7 J.Tinbergen, International Economic Integration, Elsevier, Amsterdam 1954, s. 95. 
Znaczącą rolę w procesach integracyjnych odgrywają instytucje (łac. institutio). Przedstawiciele nauk społecznych nazywają je regulatorami zmian zachodzących w gospodarce. Warto podkreślić, że dotychczas nie wypracowano jednorodnej definicji instytucji. Pojęcie instytucji jest wielowymiarowe. Instytucje są bardzo interesującą kategorią społeczną

W ujęciu prawniczym instytucję definiuje się jako zespół norm opisujących dane zjawisko bądź środek regulacji danego zjawiska społecznego. Instytucją jest również system prawny obowiązujący na danym terytorium (konstytucja).

$\mathrm{Z}$ perspektywy socjologicznej często przytaczana jest definicja $\mathrm{H}$. Spencera. Jego zdaniem instytucje są czynnikami, za pomocą których dokonuje się przystosowanie niespołecznego z natury człowieka do współdziałania z innymi ludźmi ${ }^{10}$. Natomiast według R. M. MacIver'a i C. H. Page'a instytucje to formy lub warunki określające procedury, w oparciu o które funkcjonują grupy społeczne zarówno $\mathrm{w}$ sferze polityki, jak i gospodarki ${ }^{11}$.

$\mathrm{W}$ naukach ekonomicznych pojęcie instytucji łączy się z nurtem ekonomii instytucjonalnej. Zdaniem najwybitniejszego jej przedstawiciela D. C. Northa instytucje tworzą podstawowe struktury, za pomocą których ludzie budują ład pozwalający na zmniejszenie niepewności związanej z procesem gospodarowania. Instytucje kształtują relacje międzyludzkie w sferze politycznej, społecznej, ekonomicznej ${ }^{12}$. Podobnie o instytucjach wyraża się G. M. Hodgson, podkreślając, że są to stabilne systemy utrwalonych i społecznie uznanych regul, tworzących społeczne interakcje, które mają istotny wpływ na zachowania ludzkie ${ }^{13}$. Również E. Ostrom instytucje traktuje jako reguły, którymi posługują się jednostki, by móc uporząakować wszelkie zależności występujące między nimi ${ }^{14}$.

$\mathrm{Z}$ kolei S. Parto przypisuje instytucjom wiele funkcji. Po pierwsze - asocjacyjną, traktującą instytucje jako mechanizm ułatwiający interakcję interesów społecznych. Po drugie - behawioralną, przedstawiającą instytucje jako narzędzie budujące zestandaryzowane zwyczaje społeczne. Po trzecie - poznawczą, instytucje

8 Pisze o tym m.in.w swojej najnowszej książce P. Chmielewski, Homo agens. Instytucjonalizm w naukach spotecznych, Wydawnictwo Poltext, Warszawa 2011.

9 T. Gaweł, M. Klimczak, Pojęcie instytucji w prawie i ekonomii, [w:] B. Polszakiewicz, J. Boehlke (red.), Ead instytucjonalny w gospodarce, „Ekonomia i Prawo” 2005, t. I, Wydawnictwo Uniwersytetu Mikołaja Kopernika, Toruń, s. 73-77.

10 J. Szacki, Historia myśli socjologicznej, Wydawnictwo Naukowe PWN, Warszawa 2007, s. 293.

11 R. M. MacIver, C. H. Page, Society: An Introductory Analysis, Rinehart and Co., New York 1949, s. 15.

12 D. C. North, Institutions, Institutional Change and Economic Performance, Cambridge University Press, Cambridge 2002, s. 3, 118.

13 G. M. Hodgson, The Evolution of Institutional Economics. Agency, structure and Darwinism in American Institutionalism, Routledge, London 2004, s. 424-425.

14 E. Ostrom, Crafting Institutions for Self-Governing Irrigation Systems, CA: ICS Press, San Francisco 1992, s. 19. 
pełnią tutaj funkcję modeli myślowych. Po czwarte - konstytutywną, co oznacza, że instytucje są wyznacznikami ograniczeń społecznych interakcji. Po piąte - regulacyjną, zgodnie z którą instytucje stoją na straży porządku i decydują o przestrzeganiu nakazów i zakazów ${ }^{15}$.

Instytucje są fundamentem, na którym opiera się funkcjonowanie państwa, gospodarki i społeczeństwa. Natomiast jakość instytucji ma olbrzymi wpływ na sprawność i efektywność tego funkcjonowania.Instytucje, traktowane jako wytwory życia społecznego, w sposób systematyczny i trwały determinują zachowania ludzi. Dzięki instytucjom stają się one uporządkowane i w miarę przewidywalne. W sferze społecznej instytucje powstają spontanicznie, często w drodze ewolucji. Można tu wymienić: tradycje, normy etyczne, społeczne wzory zachowań czy też rutynowe sposoby myślenia. Najważniejszą instytucją regulującą zachowania ludzi jest rynek (jego różne formy). Coraz większego znaczenia nabierają normy prawne i organizacje (np. agencje, fundacje) ${ }^{16}$. Istotą funkcjonowania społeczeństwa są zatem instytucje nieformalne i formalne.

\section{DROGA POLSKI DO UNII EUROPEJSKIEJ}

Z licznych opracowań dotyczących historii integracji wynika, że na przestrzeni dziejów problematyka ta wzbudzała zainteresowanie polityków oraz przedstawicieli różnych dziedzin nauki (m.in. filozofów, ekonomistów). Dyskusja na temat koncepcji integracji krajów europejskich toczy się od starożytności do czasów współczesnych.

Zagadnienie integracji nie jest nowe również w polskiej literaturze. W opracowaniach z przełomu XVIII i XIX wieku o jednoczeniu państw wspominali znamienici Polacy, np. Stanisław Wawrzyniec Staszic (1755-1826), Adam Jerzy Czartoryski (1770-1861), Józef Maria Hoene-Wroński (1776-1853), Wojciech Bogumił Jastrzębowski (1799-1882).

Idea integracji Polski z Europą urzeczywistniła się tymczasem dopiero po roku 1989, od kiedy nasz kraj przechodzi transformację gospodarczą. Z chwilą uwolnienia się spod wpływów Związku Radzieckiego demokratyczne rządy Polski prowadziły politykę sukcesywnego zbliżania się do Wspólnoty Europejskiej (tabela 1). Warto w tym miejscu przytoczyć słowa J. Kułakowskiego - „nie wolno

15 S. Parto, Economic Activity and Institutions: Taking Stock, „Journal of Economic Issues” 2005, vol. XXXIX, no. 1, s. 39.

16 M. Marody, J. Wilkin (red.), Meandry instytucjonalizacji: dostosowania Polski do Unii Europejskiej, EU-monitoring VII, Małopolska Szkoła Administracji Publicznej Akademii Ekonomicznej w Krakowie, Fundacja im. Friedricha Eberta, Kraków 2002, s. 8. 
dopuścić do tego, by najważniejszy od dziesiątków lat proces, jaki zachodzi w naszej sferze kulturowej i geopolitycznej, odbywał się bez naszego udziału"17.

Tabela 1. Wybrane wydarzenia zbliżające Polskę do Wspólnoty Europejskiej

\begin{tabular}{|c|c|c|}
\hline LP. & Rok & WYDARZENIA \\
\hline 1 & 1989 & $\begin{array}{l}\text { umowa o handlu i współpracy handlowej i gospodarczej; } \\
\text { Polska staje się beneficjentem środków z funduszu Poland and Hungary: Assistance for Restructuring their } \\
\text { Economies (PHARE) }\end{array}$ \\
\hline 2 & 1990 & $\begin{array}{l}\text { propozycja umów stowarzyszeniowych dla państw byłego bloku wschodniego ze strony przewodniczącego } \\
\text { Komisji Europejskiej J. Delorsa }\end{array}$ \\
\hline 3 & 1991 & $\begin{array}{l}\text { powołanie stanowiska Pełnomocnika Rządu ds. Integracji Europejskiej i Pomocy Zagranicznej; } \\
\text { podpisanie umowy o stowarzyszeniu ze Wspólnotą Europejską i jej państwami członkowskimi, tzw. Układu } \\
\text { Europejskiego }\end{array}$ \\
\hline 4 & 1992 & powołanie do życia Unii Europejskiej na mocy Traktatu z Maastricht \\
\hline 5 & 1993 & ustalenie dla państw Europy Środkowo-Wschodniej warunków członkostwa w Unii Europejskiej \\
\hline 6 & 1994 & $\begin{array}{l}\text { wejście w życie układu stowarzyszeniowego Polski z Unią Europejską; } \\
\text { oficjalny wniosek Polski o członkostwo w Unii Europejskiej; } \\
\text { przyjęcie przez UE strategii przedakcesyjnej dla państw Europy Środkowo-Wschodniej }\end{array}$ \\
\hline 7 & 1995 & $\begin{array}{l}\text { przedstawienie „Białej Księgi", gdzie zostały zawarte wymogi członkostwa w Unii Europejskiej dla państw } \\
\text { Europy Środkowo-Wschodniej }\end{array}$ \\
\hline 8 & 1996 & utworzenie Komitetu Integracji Europejskiej \\
\hline 9 & 1997 & $\begin{array}{l}\text { uchwalenie Narodowej Strategii Integracji; } \\
\text { decyzja Komisji Europejskiej o zaproszeniu Polski do rozmów na temat przystąpienia do Unii Europejskiej; } \\
\text { ogłoszenie przez przewodniczącego Komisji Europejskiej J. Santera „Agendy 2000”; } \\
\text { podpisanie Traktatu Amsterdamskiego; } \\
\text { zaproszenie Polski do negocjacji akcesyjnych }\end{array}$ \\
\hline 10 & 1998 & rozpoczęcie rokowań akcesyjnych, ogłoszenie „Partnerstwa dla członkostwa” \\
\hline 11 & 1999 & $\begin{array}{l}\text { przekazywanie Unii Europejskiej przez Polskę stanowisk negocjacyjnych w różnych obszarach społeczno- } \\
\text {-gospodarczych }\end{array}$ \\
\hline 12 & 2000 & $\begin{array}{l}\text { Rada Unii Europejskiej przyjmuje „Strategię rozszerzenia Unii Europejskiej” - dokument, który usystematy- } \\
\text { zował kalendarz negocjacji akcesyjnych }\end{array}$ \\
\hline 13 & 2001 & podpisanie Traktatu Nicejskiego \\
\hline 14 & 2002 & zakończenie negocjacji akcesyjnych między Polską i Unią Europejską \\
\hline 15 & 2003 & $\begin{array}{l}\text { przyjęcie przez Radę Unii Europejskiej projektu Traktatu Akcesyjnego; } \\
\text { podpisanie Traktatu Akcesyjnego przez przedstawicieli } 25 \text { państw - } 15 \text { państw członkowskich i } 10 \text { kandy- } \\
\text { dujących do członkostwa; } \\
\text { ogólnokrajowe referendum w sprawie przystąpienia Polski do UE }\end{array}$ \\
\hline 16 & 2004 & Polska zostaje członkiem Unii Europejskiej \\
\hline
\end{tabular}

Źródło: opracowanie własne.

17 J. Kułakowski, Polska wobec integracji europejskiej, [w:] A. Maksymowicz (red.), Polska a integracja europejska, Instytut Rozwoju Śląska, Wrocław 2000, s. 10. 
Jak podkreśla B. Rosamond, procesy integracyjne narzuciły państwom aspirującym do członkostwa we Wspólnocie Europejskiej (w tym Polsce) określone plany działania i terminy ich realizacji. Skutkowało to powstaniem więzi instytucjonalnych między Unią Europejską a krajami kandydującymi do jej struktur ${ }^{18}$.

W tabeli 1 ujęte zostały wybrane wydarzenia poprzedzające przyjęcie Polski do grona państw Unii Europejskiej. W 1989 roku między Polską i Wspólnotą Europejską została podpisana Umowa o handlu i współpracy handlowej i gospodarczej. Nasz kraj obok Węgier stał się adresatem środków z funduszu Poland and Hungary Assistance for Restructuring their Economies (PHARE).

Dwa lata później, w efekcie m.in. wyrazistych, zadowalających przedstawicieli Unii, przeobrażeń społeczno-gospodarczych, doszło do podpisania Układu Europejskiego - umowy o stowarzyszeniu Polski ze Wspólnotą Europejską. Cele stowarzyszenia sprowadzały się do ustanowienia odpowiednich ram dialogu politycznego oraz stworzenia podstaw obustronnej współpracy ekonomicznej, umożliwiających w przyszłości członkostwo Polski we Wspólnocie.

W 1993 roku na szczycie UE w Kopenhadze ustalone zostały warunki akcesji dla państw aspirujących do struktur europejskich. Przyjęte zostały kryteria polityczne członkostwa, ze szczególnym wskazaniem na utrzymywanie stabilności instytucji utrwalających demokrację i rządów prawa. Wskazano również na gospodarcze fundamenty państw zmierzających do Unii, dotyczące kwestii przestrzegania zasad gospodarki rynkowej oraz budowy potencjału gospodarczego potrafiącego sprostać presji konkurencji i siłom rynkowym. $Z$ punktu widzenia kraju kandydującego istotne były także aspekty prawno-instytucjonalne, które zobowiązywały do adaptacji dorobku prawnego Unii oraz stosowania się do jej założeń politycznych i społeczno-ekonomicznych.

Bardzo ważny dla przyszłości naszego kraju był rok 1994, kiedy Polska złożyła oficjalny wniosek o członkostwo w Unii Europejskiej. W odpowiedzi UE ogłosiła tzw. „Białą Księgę”, w której zostały zawarte wymogi członkostwa dla krajów Europy Środkowo-Wschodniej aspirujących do struktur Wspólnoty Europejskiej. W latach 1996-1997 w Polsce został powołany Komitet Integracji Europejskiej oraz została uchwalona Narodowa Strategia Integracji. Po okresie intensywnych rokowań oraz spełnieniu przez Polskę „warunków progowych” narzuconych przez UE, 13 grudnia 2002 roku zostały zakończone negocjacje akcesyjne. Pełnoprawnym członkiem Unii Europejskiej Polska została 1 maja 2004 roku.

W raporcie 5 lat Polski w Unii Europejskiej proces rozszerzenia Unii Europejskiej uznano za najbardziej udany projekt polityczny pierwszej dekady XXI wieku. Podkreślono także, że okres przygotowawczy do członkostwa był poważnym

18 Szerzej zob. B. Rosamond, Theories of European Integration, MacMillan Press, London 2000, s. 74-98. 
sprawdzianem dla krajów przystępujących do struktur unijnych zarówno w sferze politycznej, jak i społeczno-gospodarczej ${ }^{19}$. Dotyczyło to zwłaszcza budowy podstaw spójności instytucjonalnej między Unią a beneficjentami członkostwa.

\section{INSTYTUCJONALNY WYMIAR CZŁONKOSTWA POLSKI W UNII EUROPEJSKIEJ}

W 1989 roku przed Polską otworzyły się nowe możliwości rozwoju gospodarczego. Pojawiła się perspektywa szybszego niż dotychczas zbliżenia się do Europy. Bardzo wymownie skonstatował to J. Kułakowski: „Gdy nareszcie nadszedł długo oczekiwany moment, w którym Polska, znająca cenę międzynarodowego ostracyzmu, obojętności, wiedząca, czym jest brak suwerenności, mogła sama zdecydować, w którym kierunku chce iść, czy rozsądnym by było zrezygnować z okazji, jaką jest udział w integracji kontynentu? Historia rzadko daje kilka razy jakąś szansę"20. Polskę czekało wiele pracy wymaganej do spełnienia warunków, jakie stały się niezbędne, by nasz kraj mógł zostać zaliczony w poczet członków Unii Europejskiej.

Olbrzymie znaczenie w procesie dążenia Polski do struktur Wspólnoty Europejskiej miały szeroko rozumiane instytucje. Dbałość o prawidłową konstrukcję systemu instytucjonalnego stała się jednocześnie kryterium pożądanych przeobrażeń umożliwiających proces integracji z Unią Europejską.

W EU-monitoring $V I$, skrupulatnie przygotowanym pod redakcją M. Marody i J. Wilkina, czytamy, że proces przygotowań Polski do integracji z Unią Europejską był bardzo istotnym bodźcem do kolejnej fali reform instytucjonalnych od czasu rozpoczęcia transformacji systemowej, określanej mianem wielkiej zmiany instytucjonalnej. Dostosowania polskiej rzeczywistości społeczno-gospodarczej do systemu instytucjonalnego UE stały się dla naszego kraju dużym wyzwaniem. Szczególnego znaczenia nabrała konieczność adaptacji specyficznego dorobku prawnego Wspólnoty oraz utworzenie organizacji (m.in. agencji rządowych) zajmujących się realizacją polityki unijnej. Pojawił się również wymóg reorganizacji funkcjonujących w Polsce od przełomu lat 80. i 90. instytucji demokratycznych i rynkowych, mającej na celu poprawę sprawności i efektywności ich działania ${ }^{21}$.

System instytucjonalny gospodarki powinien być modyfikowany bądź budowany w oparciu o model instytucjonalizacji. Zgodnie z propozycją R. O. Keohane

195 lat w Unii Europejskiej. Raport, Urząd Komitetu Integracji Europejskiej, Warszawa 2009, s. 369.

20 J. Kułakowski, op. cit., s. 11.

21 M. Marody, J. Wilkin (red.), Meandry..., s. 9. 
instytucjonalizacja jest sposobem utrwalania wszelkich rodzajów relacji społecznych. Proces ten towarzyszy również kształtowaniu stosunków międzynarodowych i nabiera coraz większego znaczenia wraz z tym rozwojem ${ }^{22}$.

Jeden $\mathrm{z}$ bardziej interesujących modeli instytucjonalizacji zaproponowali P. S. Tolbert i L. G. Zucker (rysunek 1) ${ }^{23}$. Na tę propozycję instytucjonalizacji uwagę zwracają również inni autorzy, m.in. W. Morawski² ${ }^{24}$ M. Cantero ${ }^{25}$.

W ramach modelu instytucjonalizacji, który przedstawili P. S. Tolbert i L. G. Zucker, zostały wyróżnione:

- innowacje, na które istotny wpływ wywierają zmiany technologiczne, działania legislacyjne struktur władzy oraz siły rynkowe;

- habituacja rozumiana jako proces tworzenia nowych struktur i procedur działania mających na celu rozwiązywanie pojawiających się problemów;

- obiektywizacja - działanie zmierzające do absorpcji innowacji w postaci wspomnianych wcześniej nowych struktur (odbywa się to na zasadzie teoretyzowania - badania i uzasadniania wyników oraz pełnego monitoringu);

- sedymentacja, co oznacza utrwalenie pozytywnych efektów innowacji na skutek poparcia różnych grup interesu, jak również przełamania oporu niezadowolonych.

W przypadku Polski dążącej do członkostwa w Unii Europejskiej reorganizacja systemu instytucjonalnego gospodarki (budowa nowych instytucji, adaptacja instytucji już istniejących bądź ich modyfikacja) odbywała się pod wpływem czynników politycznych, społecznych i gospodarczych, zarówno o charakterze endogenicznym, jak i egzogenicznym. Pojawienie się nowych rozwiązań instytucjonalnych nie zawsze oznacza postęp. Nowo powstałe instytucje mogą być ułomne i nieefektywne i nie odpowiadać potrzebom danego etapu rozwoju. Nie zawsze też pojawiające się instytucje zyskują społeczne zakorzenienie w wytworzonych wcześniej nawykach działania i myślenia ${ }^{26}$. Nie mogą zatem podlegać procesom dostosowawczym, które całkowicie zmieniają logikę ich funkcjonowania ${ }^{27}$.

22 R. O. Keohane, International institutions: two approaches, [w:] J. der Derian (red.), International Theory: Critical Investigation, McMillan, London 1995, s. 279-307.

23 P. S. Tolbert, L. G. Zucker, The Institutionalization of Institutional Theory, „Handbook of Organization Studies", (ed.) S. R. Clegg, C. Hardy, W. R. Nord, Sage Publications, London 2003.

24 W. Morawski, Socjologia ekonomiczna, Wydawnictwo Naukowe PWN, Warszawa 2001, s. 61.

25 M. Cantero, Processes of Institutionalization. A Proposal for a Model of the Mexican Case, "The International Journal of Knowledge, Culture and Change Management in Organisations" 2005, vol. 5 , s. 6 .

${ }^{26} \mathrm{~J}$. Tischner zwraca uwagę na trwanie polskiego społeczeństwa w strukturach tzw. homo sovieticus, człowieka, którego umysł jest zniewolony przez system komunistyczny i jest niezdolny do akceptacji jakichkolwiek zmian. Homo sovieticus ma olbrzymie trudności z przezwyciężeniem ukształtowanych w jego umyśle nawyków, sposobów działania i myślenia; J. Tischner, Etyka solidarności oraz homo sovieticus, Wydawnictwo Znak, Kraków 2005, s. 141-145.

27 M. Marody, J.Wilkin (red.), Meandry..., s. 9. 


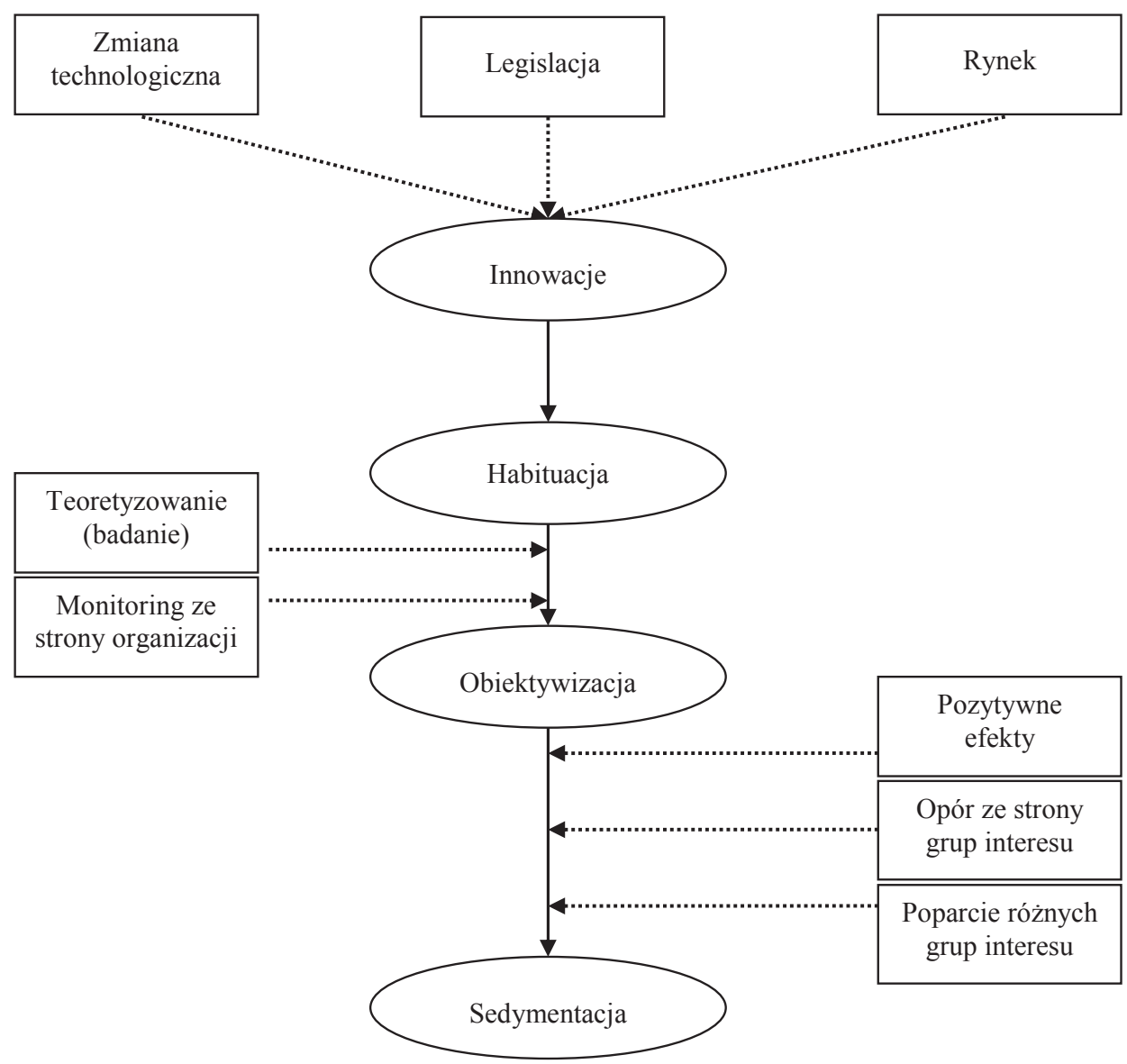

Rysunek 1. Proces instytucjonalizacji

Źródło: P. S. Tolbert, L. G. Zucker, The Institutionalization of Institutional Theory , „Handbook of Organization Studies", (ed.) S. R. Clegg, C. Hardy, W. R. Nord, Sage Publications, London 2003, s. 182.

Jak podkreśla U. Płowiec, warunki członkostwa Polski w Unii Europejskiej były trudne do zaakceptowania dla większości polskiego społeczeństwa, również części polityków. W okresie przed akcesją częściej zwracano uwagę na koszty naszego członkostwa we Wspólnocie niż na korzyści. Nie dostrzegano pozytywnych stron integracji, takich jak awans cywilizacyjny naszego kraju, wzrost nakładów na modernizację polskiej gospodarki czy wprowadzenie nowych metod zarządzania państwem ${ }^{28}$. s. 627.

U. Płowiec, Polska w Unii Europejskiej - kilka refleksji o przysztości, „Ekonomista” 2011, nr 4, 
Istotną kwestią dostosowań Polski do Unii Europejskiej było dokonanie zmian instytucjonalnych zarówno w sferze politycznej, jak i społeczno-gospodarczej. W tym miejscu należy wymienić działania zmierzające do ukształtowania:

- instytucji niezbędnych do formalnego uczestnictwa naszego kraju w systemie Unii Europejskiej, stanowiących minimum instytucjonalnej spójności przyszłych członków i ówczesnej Unii - adaptacja dorobku prawnego Wspólnoty, w efekcie czego wzrosła kompatybilność systemów politycznych i gospodarczych obu stron;

- instytucji wzmacniających konkurencyjność poszczególnych gospodarek, bądź ich części na rynku unijnym oraz globalnym - adaptacja norm handlowych i zasad umożliwiających swobodę przenoszenia czynników produkcji na obszarze Wspólnoty;

- instytucji stwarzających możliwości efektywnego wykorzystania funduszy Unii Europejskiej, przeznaczonych na realizację polityki wspólnotowej (rolnej, strukturalnej, regionalnej) ${ }^{29}$.

W okresie poprzedzającym rozszerzenie Wspólnota Europejska realizowała politykę wspomagania i mobilizowania krajów kandydujących do UE. K. Żukrowska zaznacza, że proces przygotowań był posiłkowany wypełnianiem przez UE kilku istotnych funkcji. Były to działania z zakresu oceny stanu zaawansowania reform w krajach ubiegających się o członkostwo oraz określania priorytetów pomocy i koordynacji wsparcia. Ponadto ważnym zadaniem realizowanym przez Wspólnotę było wyznaczanie kierunków i dynamiki zmian w różnych sferach dostosowan ${ }^{30}$, np. systemie prawnym czy też w poszczególnych sektorach gospodarki. Istotnym zagadnieniem były także procesy demokratyzacji kraju oraz wdrażanie mechanizmu rynkowego w gospodarce.

Według M. Marody i J. Wilkina dojrzała demokracja i system rynkowy opierają się na trzech filarach, do których należy dążyć. Są to: „dobre państwo” (sprawne i sprawiedliwe), efektywny rynek wspierany rozbudowaną siecią instytucji oraz społeczeństwo obywatelskie, mające silne oparcie w różnego rodzaju organizacjach. W okresie poprzedzającym członkostwo Polski w Unii Europejskiej w naszym kraju zbudowane zostały podstawy demokratycznego państwa i gospodarki rynkowej.Jednak, co sygnalizują autorzy raportu EU-monitoring $V I$, polska demokracja i system rynkowy były słabo, bądź ułomnie zinstytucjonalizowane ${ }^{31}$.

29 M. Marody, J. Wilkin (red.), Meandry..., s. 134-135.

30 K. Żukrowska, Transformacja gospodarcza w warunkach integracji z Uniq Europejska, [w:] S. Lis, S. Miklaszewski (red.), Transformacja, integracja, globalizacja. W poszukiwaniu modelu rozwoju gospodarczego Polski, Akademia Ekonomiczna w Krakowie, Małopolska Wyższa Szkoła Ekonomiczna w Tarnowie, Kraków-Tarnów 2004, s. 128-129.

31 M. Marody, J. Wilkin (red.), Meandry..., s. 9. 
Mimo to władze UE, przyjmując Polskę do struktur Wspólnoty, uznały, że nasz kraj ma istotne dla procesów integracyjnych cechy gospodarki rynkowej i demokratycznego państwa. Osiągnięcie takiego stanu reform systemowych było najważniejszym celem, jaki realizowano w Polsce po 1989 roku $^{32}$.

Od jakości struktur instytucjonalnych utworzonych w wyniku transformacji zależało tempo i rozmiary narastania korzyści z członkostwa w Unii. Gruntowna przebudowa struktur instytucjonalnych we wszystkich dziedzinach życia gospodarczego, społecznego i politycznego była również głównym warunkiem przystąpienia Polski do UE. Reformy podstawowych instytucji systemowych zakończyły się znaczącym sukcesem (m.in. urynkowienie gospodarki). Proces zmian instytucjonalnych, zwłaszcza w sferze instytucji nieformalnych (postawy, tradycje, wzory postępowania i myślenia itp.), przebiegał opornie. Instytucje formalne, takie jak normy prawne czy nowe organizacje (agencje, fundacje), można ustanowić stosunkowo szybko, ale ich społeczne zakorzenienie i legitymizacja przebiegają znacznie wolniej ${ }^{33}$.

Integracja Polski z Unią Europejską była ważnym testem komplementarności, spójności i efektywności instytucji zbudowanych w okresie poprzedzającym akcesję. Adaptacja do struktur unijnych nie zakończyła się w momencie przyjęcia Polski do UE. Procesy dostosowawcze trwają również obecnie, kiedy Polska jest już pełnoprawnym członkiem Unii. Wzorem mogą być tutaj doświadczenia akomodacyjne krajów przyjętych do Wspólnoty Europejskiej w okresie wcześniejszym $^{34}$. Zaproponowane przez Unię Europejską instytucjonalne podstawy akcesji można określić mianem „warunków progowych” zapewniających minimum spójności systemów gospodarczych Polski i UE ${ }^{35}$.

Czy Polacy mają się bać członkostwa w Unii Europejskiej? Odpowiedź brzmi: nie! Można ją poprzeć stwierdzeniem S. Stebelskiego: „dysponujemy szeregiem atutów, wynikających z położenia geograficznego, potencjału ludnościowego i gospodarczego, własnego dorobku cywilizacyjnego. Nie musimy obawiać się utraty własnej tożsamości. Polska jest zbyt dużym krajem, aby mogło jej grozić takie niebezpieczeństwo. Polska stanęła natomiast przed szansą umocnienia swojej pozycji w regionie i w Europie" 36 .

32 M. Marody, J. Wilkin (red.), Na prostej? Polska w przededniu cztonkostwa w UE. EU-monitoring VII, Małopolska Szkoła Administracji Publicznej Akademii Ekonomicznej w Krakowie, Fundacja im. Friedricha Eberta, Kraków 2003, s. 7.

33 M. Marody, J. Wilkin (red.), Na prostej..., s. 8.

34 Przekroczenie progu Unii wiąże się z ciągłym doskonaleniem rozwiązań instytucjonalnych, których dopiero właściwa konstrukcja sprawi, że z integracji można odnieść korzyści; M. Marody, J. Wilkin (red.), Na prostej..., s. 206.

35 M. Marody, J. Wilkin (red.), Meandry..., s. 10.

36 S. Stebelski, Zmiana uktadu sit w UE po przyjęciu Polski i innych krajów Europy Środkowej i Wschodniej, [w:] S. Miklaszewski (red.), Polska w Unii Europejskiej, Kraków 1999, s. 20. 
Jeden z zagranicznych ekonomistów, badających gospodarki państw Europy Środkowo-Wschodniej, G. de Menil, uznaje Polskę za kraj, który odniósł znaczący sukces społeczno-gospodarczy wśród państw europejskich, przechodzących transformację ustrojową ${ }^{37}$. Parafrazując jego słowa, należy stwierdzić, że istotnym osiągnięciem naszego kraju jest także członkostwo w Unii Europejskiej. Droga Polski do struktur unijnych, podobnie jak historia polskiej transformacji, nie jest jednak wzorcowym przykładem doskonałości.

\section{ZAKOŃCZENIE}

Przełom lat 80. i 90. XX wieku był początkiem tworzenia więzi ekonomicznych, społecznych i politycznych - procesu mającego olbrzymi wpływ na konsolidację polskiej gospodarki z gospodarką unijną. Konstrukcja sieci instytucji, właściwej dla funkcjonowania Polski w systemie gospodarki kapitalistycznej, stała się również podstawą dążenia naszego kraju do struktur Unii Europejskiej - jednej z najstarszych organizacji gospodarczych na świecie. Działania takie stały się motorem rozwoju gospodarczego oraz źródłem awansu cywilizacyjnego Polski.

Członkostwo we Wspólnocie Europejskiej należy uznać za czynnik ugruntowujący pozycję Polski na arenie międzynarodowej. Uzyskanie spójności instytucjonalnej z państwami Unii otworzyło Polsce drogę do przyspieszonego rozwoju gospodarczego. Ważne jest, by stworzona w naszym kraju sieć instytucji charakteryzowała się względną trwałością i była podatna na wszelkie korzystne przeobrażenia oraz odporna na erozję.

Jest to istotne, zwłaszcza w sytuacji, kiedy gospodarka wystawiona jest na różnego rodzaju niepowodzenia (kryzysy gospodarcze, katastrofy ekologiczne). Objawiają się wówczas słabości systemów ekonomicznych, które narażone są na niekontrolowane przeobrażenia.

37 G. de Menil, History, Policy and Performance in Two Transition Countries - Poland and Romania, [w:] D. Rodrik (ed.), In Search of Prosperity. Analytic Narratives on Economic Growth, Princeton University Press, Princeton 2003, s. 275. 


\section{BIBLIOGRAFIA}

Bajan K., Polityka gospodarcza i spoteczna. Polska w Unii Europejskiej, Wydawnictwo Naukowe Wyższej Szkoły Kupieckiej, Łódź 2005.

Balassa B., The Theory of Economic Integration, George Allen \& Unwin, London 1962.

Cantero M., Processes of Institutionalization. A Proposal for a Model of the Mexican Case, „The International Journal of Knowledge, Culture and Change Management in Organisations" 2005, vol. 5.

Chmielewski P., Homo agens. Instytucjonalizm w naukach społecznych, Wydawnictwo Poltext, Warszawa 2011.

Gaweł T., Klimczak M., Pojęcie instytucji w prawie i ekonomii, [w:] B. Polszakiewicz, J. Boehlke (red.), Ead instytucjonalny w gospodarce, „Ekonomia i Prawo” 2005, t. I, Wydawnictwo Uniwersytetu Mikołaja Kopernika, Toruń.

Hodgson G. M., The Evolution of Institutional Economics. Agency, structure and Darwinism in American Institutionalism, Routledge, London 2004.

Kamecki Z. J., Pojęcie i typy integracji gospodarczej, „Ekonomista” 1967, nr 1.

Keohane R. O., International institutions: two approaches, [w:] J. der Derian (red.), International Theory: Critical Investigation, McMillan, London 1995.

Kułakowski J., Polska wobec integracji europejskiej, [w:] A. Maksymowicz (red.), Polska a integracja europejska, Instytut Rozwoju Śląska, Wrocław 2000.

Łastawski K., Historia integracji europejskiej, Wydawnictwo Adam Marszałek, Torun 2011.

Machlup F., Integracja gospodarcza - narodziny i rozwój idei, Państwowe Wydawnictwo Naukowe, Warszawa 1986.

MacIver R. M., Page C. H., Society: An Introductory Analysis, Rinehart and Co., New York 1949.

Marody M., Wilkin J. (red.), Meandry instytucjonalizacji: dostosowania Polski do Unii Europejskiej, EU-monitoring VII, Małopolska Szkoła Administracji Publicznej Akademii Ekonomicznej w Krakowie, Fundacja im. Friedricha Eberta, Kraków 2002.

Marody M., Wilkin J. (red.), Na prostej? Polska w przededniu członkostwa w UE. EU-monitoring VII, Małopolska Szkoła Administracji Publicznej Akademii Ekonomicznej w Krakowie, Fundacja im. Friedricha Eberta, Kraków 2003.

McCormick J., Zrozumieć Unię Europejską, Wydawnictwo Naukowe PWN, Warszawa 2010.

Menil G. de, History, Policy and Performance in Two Transition Countries - Poland and Romania, [w:] D. Rodrik (ed.), In Search of Prosperity. Analytic Narratives on Economic Growth, Princeton University Press, Princeton 2003.

Morawski W., Socjologia ekonomiczna, Wydawnictwo Naukowe PWN, Warszawa 2001.

North D. C., Institutions, Institutional Change and Economic Performance, Cambridge University Press, Cambridge 2002.

Ostrom E., Crafting Institutions for Self-Governing Irrigation Systems, CA: ICS Press, San Francisco 1992.

Parto S., Economic Activity and Institutions: Taking Stock, "Journal of Economic Issues" 2005, vol. XXXIX, no. 1. 
5 lat w Unii Europejskiej. Raport, Urząd Komitetu Integracji Europejskiej, Warszawa 2009. Płowiec U., Polska w Unii Europejskiej - kilka refleksji o przysztości, „Ekonomista” 2011, nr 4.

Rosamond B., Theories of European Integration, MacMillan Press, London 2000.

Stebelski S., Zmiana uktadu sit w UE po przyjęciu Polski i innych krajów Europy Środkowej i Wschodniej, [w:] S. Miklaszewski (red.), Polska w Unii Europejskiej, Kraków 1999.

Szacki J., Historia myśli socjologicznej, Wydawnictwo Naukowe PWN, Warszawa 2007. Tinbergen J., International Economic Integration, Elsevier, Amsterdam 1954.

Tischner J., Etyka solidarności oraz homo sovieticus, Wydawnictwo Znak, Kraków 2005.

Tolbert P. S., Zucker L. G., The Institutionalization of Institutional Theory, „Handbook of Organization Studies", S. R. Clegg, C. Hardy, W. R. Nord (ed.), Sage Publications, London 2003.

Żukrowska K., Transformacja gospodarcza w warunkach integracji z Uniq Europejskq, [w:] S. Lis, S. Miklaszewski (red.), Transformacja, integracja, globalizacja. W poszukiwaniu modelu rozwoju gospodarczego Polski, Akademia Ekonomiczna w Krakowie, Małopolska Wyższa Szkoła Ekonomiczna w Tarnowie, Kraków-Tarnów 2004.

\title{
STRESZCZENIE
}

Badania z zakresu integracji gospodarczej zajmują znaczącą pozycję w literaturze naukowej. Proces konsolidacji gospodarek, zwłaszcza w Europie w ramach rozbudowy Unii Europejskiej, jest istotą rozważań przedstawicieli różnych nauk społecznych, głównie ekonomistów. W niniejszym artykule poruszone zostały zagadnienia dotyczące przygotowań Polski do akcesji do Unii Europejskiej. Analizę przeprowadzono z perspektywy historycznej oraz w oparciu o narzędzia ekonomii instytucjonalnej.

\section{INSTITUTIONAL FOUNDATIONS OF POLAND'S ACCESSION TO THE EUROPEAN UNION}

\author{
SUMMARY
}

Research on economic integration constitutes a significant position in the scientific literature. The process of consolidation of the economies, particularly in Europe, as an expansion of the European Union, is the essence of a debate between representatives from the various social sciences, especially economists. This article focuses on Poland's preparations for accession into the European Union. The analysis was performed from a historical perspective, using the tools of institutional economics. 